\title{
Model Numerik Nays2DH untuk Penempatan Bangunan Krib pada Belokan Sungai
}

\author{
Apria Wayah Patra S.N ${ }^{1 *}$, Dwi Priyantoro ${ }^{1}$, Dian Sisinggih ${ }^{1}$ \\ ${ }^{1}$ Jurusan Teknik Pengairan, Fakultas Teknik, Universitas Brawijaya, \\ Jalan MT. Haryono No. 167, Malang, 65145, INDONESIA \\ *Korespondensi Email: apria.wayah14@gmail.com
}

\begin{abstract}
River flow has the power to change the surface of the earth. At a curve in the river, the river flow can scour depth along the outer bank of river curves, thus affecting people in the surrounding area. The purpose of this study was to find to which of the perpendicular, downstream, or upstream inclined groin formations could reduce the scour that occurred at the curve of the Ciasem River. The data sourced from the River and Swamp Water Engineering Laboratory will be processed, tested, and analyzed in dominant and flood discharge conditions in a mathematical model using the Nays2DH. After testing, it can be decided the scour location for further installation of the groins on the Nays $2 \mathrm{DH}$. The trial results show that the perpendicular groin formation is the best because it capable of directing the scour away from the outer curve of the river to reduce its scour
\end{abstract}

Keywords: Ciasem River, Groin, Nays2DH

Abstrak: Aliran sungai mempunyai kekuatan untuk melakukan perubahan muka bumi. Pada tikungan sungai aliran sungai mampu tikungan untuk melakukan gerusan pada tikungan pada sisi luar sehingga dapat merugikan masyarakat di sekitar area tersebut. Studi ini dilakukan untuk menemukan mana diantara formasi tegak lurus, condong hilir, atau hulu yang mampu mengurangi gerusan yang terjadi pada tikungan Sungai Ciasem. Data yang di gunakan bersumber dari Laboratorium Sungai dan Rawa Teknik Pengairan yang nantinya akan di olah, di uji coba serta d analisa pada kondisi debit dominan dan banjir pada model matematik menggunakan Nays2DH. Lalu setelah di lakukan uji coba dapat ditenukan lokasi gerusan untuk selanjutnya dilakukan pemasangan krib pada Nays2DH. Hasil uji coba menunjukan bahwa dari ketiga formasi yang di uji coba, formasi tegak lurus adalah formasi yang mampu mengarahkan gerusan menjauhi tikungan luar sungai sehingga dapat mengurangi gerusanya.

Kata kunci: Krib, Nays2DH, Sungai Ciasem 


\section{Pendahuluan}

Sungai adalah suatu saluran drainase yang terbentuk secara alamiah [1]. Pada sungai dimana kecepatan arusnya tinggi tentu menimbulkan erosi, baik yang tejadi di tebing maupun di dasar sungai [2]. Persoalan sungai yang menarik untuk diamati adalah terjadinya perubahan morfologi sungai. Perubahan ini terjadi secara alami maupun karena banyaknya perlakuan yang ada di sepanjang sungai, missal adanya bendungan, waduk, jembatan, dan karena kondisi alam yang tidak dapat dihindarkan seperti adanya tikungan sungai [3].

Belokan sungai merupakan fenomena yang spesifik untuk di kaji, karena pada belokan sungai sering terjadi permasalahan erosi pada dasar dan tebing sungai akibat pukulan air[4]. Perubahan dasar dan tebing dapat menyebabkan ketidakseimbangan angkutan sedimen sehingga perlu ditempatkan beberapa bangunan control untuk menyeimbangkan kondisi sungai [5], Salah satu bangunan control untuk menyeimbangkan dasar sungai yang dapat melindungi dasar dan tebing sungai pada belokan adalah pemasangan krib [6].

Salah satu metode untuk melindungi tebing sungai adalah dengan menggunakan bangunan krib [7]. Krib merupakan suatu bentuk pelindung tebing secara tidak langsung yang digunakan untuk melindungi tebing sungai secara tidak langsung dari bahaya gerusan lokal dan gejala meander karena arus [8]. Krib juga dapat menjadi sarana untuk memperkecil luas penampang secara terbatas dan dapat dimanfaatkan untuk memperbesar kecepatan aliran [9] sehingga diharapkan mampu mengatasi masalah yang terjadi.

Masalah yang terjadi pada Sungai Ciasem adalah gerusan pada sisi luar tikungan yang mampu menggerus tebing dan dasar sungai sehingga mampu dapat menyebabkan adanya kerugian yaitu bencana longsor tebing. Pada survey lapangan yang dilakukan pada tahun 2020 terlihat bahwa terjadi longsor tebing pada lokasi studi yang menyebabkan tegerusnya lahan pertanian dan akses jalan warga.

Tujuan dari studi ini ialah mendapatkan formasi yang mampu mengurangi gerusan pada tikungan luar sungai dengan menggunakan model matematik Nays2DH agar dapat melihat bagaimana masing masing formasi krib memindahkan gerusan menjauhi sisi tikungan luar dari Sungai Ciasem.

\section{Bahan dan Metode}

Bagian bahan dan metode, atau dikenal sebagai metodologi penelitian, menjelaskan semua informasi yang diperlukan untuk mendapatkan hasil penelitian

\subsection{Bahan}

Daerah Aliran Sungai (DAS) Ciasem merupakan salah satu DAS yang berada di satuan Wilayah Sungai (WS) Citarum dengan hulu sungai berada di Gunung Tangkuban Parahu dan bermuara di Teluk Ciasem dengan panjang sungai $184,9 \mathrm{~km}$ dan luas $734,1 \mathrm{~km}^{2}$. Kawasan DAS Ciasem terdiri atas tiga zona, yaitu hulu, tengah, dan hilir yang mencakup 12 kecamatan dalam wilayah administratif Kabupaten Subang. Penelitian dilaksanakan di wilayah hulu DAS Ciasem yang meliputi Kecamatan Sagalaherang, Jalancagak, dan Cijambe yang termasuk dalam Wilayah Pengembangan (WP) Jalancagak, Kabupaten Subang [10]. 


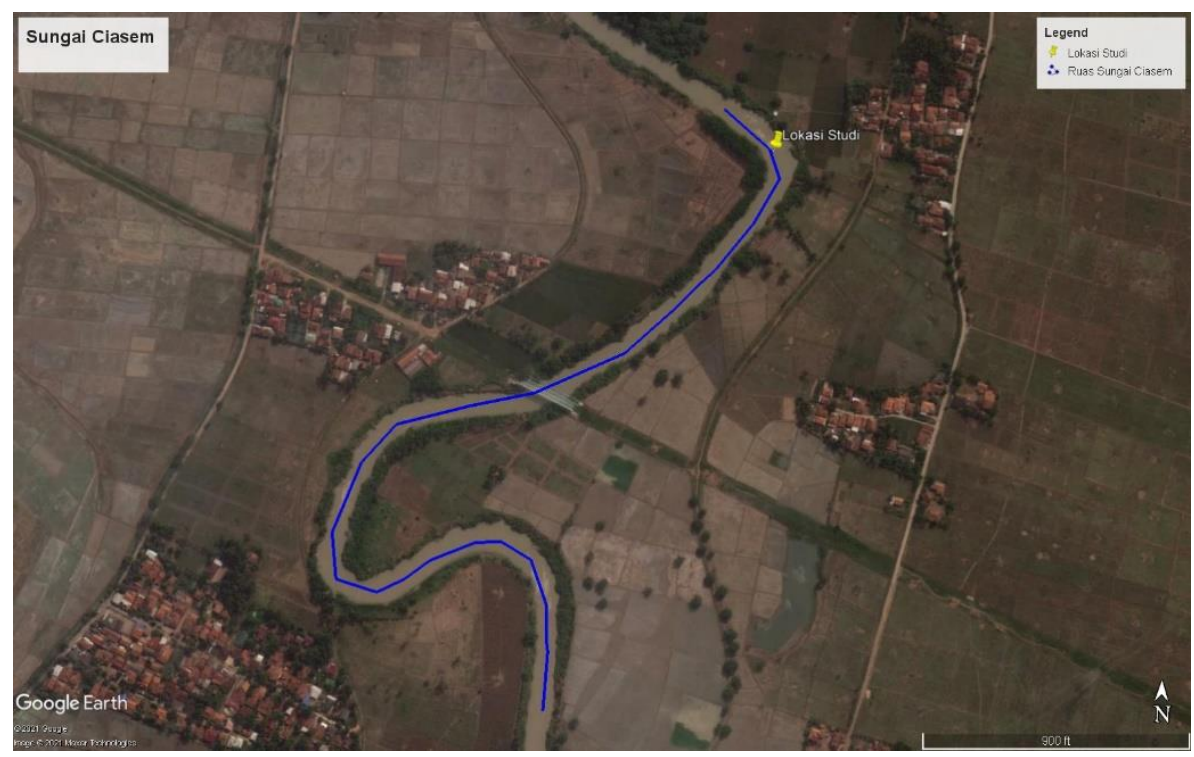

Gambar 1: Peta Administrasi Kabupaten Subang

Pengumpulan data-data untuk studi penempatan formasi bangunan pengarah aliran pada belokan Sungai Ciasem, Kecamatan Ciasem, Kabupaten Subang. dilakukan secara sekunder dengan data-data yang di gunakan pada studi ini adalah sebagai berikut :

- Data topografi Sungai Ciasem

- Data debit dominan $\left(26,83 \mathrm{~m}^{3} / \mathrm{s}\right.$.) dan banjir $\left(53,67 \mathrm{~m}^{3} / \mathrm{s}\right)$

- Data gradasi sedimen

- Hasil uji lab model fisik Sungai Ciasem

Alat bantu yang digunakan dalam studi ini antara lain

- Perangkat lunak Microsoft Excel untuk menghitung gerusan lokal dengan Metode Farraday dan Charlton, New Zealand Railways, dan Colorado State University (CSU)

- Perangkat lunak International River Interface Cooperative (Nays2DH) untuk mengamati pola gerusan yang terjadi pada dasar sungai.

\subsection{Metode}

Sebelum dilakukan penelitian, dikumpulkan data topografi, data debit, data gradasi sedimen ,dan Hasil uji lab model fisik Ciasem, setelah itu dilakukan pembuatan model matematik menggunakan Nays2DH, selanjutnya adalah melakukan kalibrasi kemiringan pada model yang telah dibuat. Setelah model teruji maka selanjutnya dilakukan ujicoba dan analisa model Nays2DH sebelum terpasang krib dengan debit dominan dan banjir. Langkah berikutnya adalah melakukan perhitungan Brier Skill Score (BSS) dengan membandingkan dengan hasil uji coba model fisik, hasil pola gerusan Nays2DH pada kondisi sebelum terpasang krib kemudian di validasi dengan model fisik. Langkah berikutnya adalah melakukan perhitungan tegangan geser pada tikungan sungai. Setelah menemukan pola gerusan yang terjadi maka direncanakan pemasangan krib yang sesuai lalu dilakukan perhitungan pola gerusan dengan tiga metode yaitu Metode Farraday dan Charlton, New Zealand Railways, dan Colorado State University (CSU). Langkah berikutnya adalah melakukan uji coba serta analisa pada debit dominan dan banjir untuk selanjutnya hasil dari ujicoba tersebut divalidasi dengan hasil model fisik. Tahap terakhir adalah menentukan formasi mana yang bekerja paling baik dalam mengatasi gerusan pada tikungan Sungai Ciasem. 


\subsection{Persamaan}

\subsubsection{Perhitungan Tegangan Geser}

Dalam penyelidikanya terhadap perilaku hidraulik pada belokan sungai, Karaki memperhatikan factor tegangan geser $(\tau)$ pada bagian sisi luar dan dalam sepanjang belokan, memperoleh hasil yang disajikan dalam bentuk grafik dan persamaan.

$$
\begin{array}{lr}
\Delta=0,42 \cdot \alpha \cdot \frac{(\text { Hmaks })}{B} \cdot g^{\frac{1}{2}} / C & \text { Pers.1 } \\
C=R^{\frac{1}{6}} / n & \text { Pers.2 }
\end{array}
$$

Dimana:

$$
\begin{array}{ll}
\Delta & =\text { parameter pembantu karaka } \\
\alpha & =\text { sudut belokan }\left({ }^{\circ}\right) \\
\text { Hmaks } & =\text { kedalaman aliran maksimum }(\mathrm{m}) \\
\mathrm{B} & =\text { lebar tampang sungai/saluran }(\mathrm{m}) \\
\mathrm{C} & =\text { koefisien kekasaran Chezy }\left(\mathrm{m}^{1 / 2} / \mathrm{s}\right) \\
\mathrm{R} & =\text { jari-jari hidraulik }(\mathrm{m}), \\
\mathrm{n} & =\text { koefisien kekasaran Manning }
\end{array}
$$

2.3.2 Perhitungan gerusan lokal dengan Metode Farraday dan Charlton

Persamaan yang digunakan dalam perhitugan gerusan lokal adalah sebagai berikut:

$$
\begin{array}{ll}
\mathrm{Y} 2=0,38(\mathrm{~V} 1 \mathrm{y} 0) 0,67 \mathrm{D} 50-0,17 & \text { Pers.3 }
\end{array}
$$

Dimana:

Y2 = Rata-rata kedalaman gerusan lokal diukur dari permukaan air $(\mathrm{m})($ Harga dari perhitungan Y2 masih harus dikalikan factor koreksi)

$\mathrm{y}_{0} \quad=\mathrm{A} 1 / \mathrm{T} 1=$ Desain kedalaman gerusan lokal $(\mathrm{m})$

$\mathrm{T} 1=$ desain lebar rata-rata permukaan aliran sungai $(\mathrm{m})$

A1 $=$ desain luas penampang rata-rata aliran sungai $\left(\mathrm{m}^{2}\right)$

V1 = desain kecepatan aliran $(\mathrm{m} / \mathrm{s})$

D50 = diameter butir material di dasar sungai $(\mathrm{mm})$, berat butiran sedimen $50 \%$ lolos Saring

2.3.3 Perhitungan gerusan lokal dengan Metode New Zealand Railways

Persamaan yang digunakan dalam perhitugan gerusan lokal adalah sebagai berikut:

$$
\begin{array}{lc}
D s=0,8 \sqrt{V o . b} & \text { Pers.4 } \\
\text { Vo }=\frac{Q}{A}\left[\frac{y o}{\frac{A}{W}}\right]^{2 / 3} \times C & \text { Pers.5 }
\end{array}
$$


Dimana:

$\mathrm{D}_{\mathrm{S} 2}=$ kedalaman gerusan lokal di ukur dari dasar alur rata-rata $(\mathrm{m})$

$\mathrm{V}_{0} \quad=$ kecepatan aliran rata-rata pada potongan melintang di udik daerah gerusan $(\mathrm{m} / \mathrm{s})$

$\mathrm{b} \quad=$ lebar efektif proyeksi pilar (m)

$\mathrm{Y}_{0} \quad=$ kedalaman air maksimum di daerah gerusan dan udiknya $(\mathrm{m})$

A = Luas penampang alur bukaan jembatan yang tegak lurus terhadap aliran sebelum terjadinya gerusan, tanpa dikurangi luas oleh luas proyeksi dari pilarpilar $\left(m^{2}\right)$

$\mathrm{W}=$ lebar total alur bukaan jembatan $(\mathrm{m})$

$\mathrm{Q}=$ debit banjir puncak di lokasi jembatan $\left(\mathrm{m}^{3} / \mathrm{s}\right)$.

$\mathrm{C}=1,2$ untuk kondisi adanya penyempitan, dan 1,0 untuk kondisi lainya

2.3.4 Perhitungan gerusan lokal dengan Metode Colorado State University

Persamaan yang digunakan dalam perhitugan gerusan lokal adalah sebagai berikut:

$$
d_{s}=2,0 \text { y } K_{1} K_{2} K_{3}\left(\frac{b}{y}\right)^{0.65} \mathrm{Fr}^{0,43}
$$

Pers.6

DImana:

$$
\begin{array}{ll}
d_{s} & =\text { kedalaman gerusan }(\mathrm{m}) \\
\mathrm{f}_{\mathrm{r}} & =\text { bilangan Froude } \\
b & =\text { lebar pilar }(\mathrm{m}) \\
y & =\text { kedalaman aliran }(\mathrm{m}) \\
K 1 & =\text { koefisien bentuk pilar } \\
K 2 & =\text { koefisien sudut aliran } \\
K 3 & =\text { koefisien kondisi dasar saluran }
\end{array}
$$

\section{Hasil dan Pembahasan}

\subsection{Kalibrasi Kemiringan Dasar Saluran}

Untuk memperoleh pendekatan kesamaan dengan prototype yang representatif digunakan pendekatan evaluasi berdasarkan kondisi kesetimbangan dasar sungai dengan penilaian berdasarkan posisi kemiringan dasar sungai pada Nays2DH terhadap kemiringan dasar eksisting. 
Tabel 1: Hasil Kalibrasi Kemiringan

\begin{tabular}{ccc}
\hline Analisa & $\begin{array}{c}\text { Nilai kemiringan } \\
\text { dasar sungai }\end{array}$ & $\begin{array}{c}\text { Prosentase kesalahan } \\
\text { terhadap slope lapangan }\end{array}$ \\
\hline Slope Lapangan & 0,00251 & \\
Slope Model Fisik & 0,00263 & $4,60 \%$ \\
Slope Nays2DH & 0,00264 & $5,03 \%$ \\
\hline
\end{tabular}

Dari tabel di atas maka dapat di simpulkan bahwa model matematik yang telah dibuat dapat digunakan untuk penelitian dengan hasil kalibrasi kemiringan sebesar 0,00264 dengan prosentase $5,03 \%$ (representatif).

3.2 Perhitungan Brier Skill Score (BSS)

Tabel 2: Hasil Perhitungan BSS

\begin{tabular}{ccccccc}
\hline No & section & Obs & Num & BS & BS $_{\text {ref }}$ & \begin{tabular}{c}
$1-$ \\
\cline { 4 - 5 }
\end{tabular} \\
\cline { 5 - 6 } & & & $(0-\mathrm{Num}-\mathrm{Obs})^{2}$ & $(\mathrm{BS} / \mathrm{Bsref})$ \\
\hline $\mathbf{1}$ & 33 & $-0,85$ & $-0,08$ & 0,5928185 & $7,225 \mathrm{E}-01$ & \\
$\mathbf{2}$ & 35 & $-0,72$ & $-0,13$ & 0,3491309 & $5,184 \mathrm{E}-01$ & \\
$\mathbf{3}$ & 36 & $-0,62$ & $-0,15$ & 0,2247746 & $3,844 \mathrm{E}-01$ & \\
$\mathbf{4}$ & 37 & $-0,58$ & $-0,31$ & 0,0741587 & $3,364 \mathrm{E}-01$ & \\
$\mathbf{5}$ & 38 & $-0,58$ & $-0,54$ & 0,0013655 & $3,364 \mathrm{E}-01$ & \\
$\mathbf{6}$ & 39 & $-0,58$ & $-0,56$ & 0,0005895 & $3,364 \mathrm{E}-01$ & \\
$\mathbf{7}$ & 40 & $-0,55$ & $-0,52$ & 0,0010126 & $3,025 \mathrm{E}-01$ & \\
$\mathbf{8}$ & 41 & $-0,46$ & $-0,43$ & 0,0008269 & $2,116 \mathrm{E}-01$ & \\
$\mathbf{9}$ & 42 & $-0,16$ & $-0,13$ & 0,0007717 & $2,560 \mathrm{E}-02$ & \\
$\mathbf{1 1}$ & 44 & 0,10 & $-0,01$ & 0,0111844 & $1,000 \mathrm{E}-02$ & \\
$\mathbf{1 2}$ & 45 & 0,18 & 0,32 & 0,0026975 & $3,240 \mathrm{E}-02$ & \\
$\mathbf{1 3}$ & 46 & 0,18 & 0,02 & 0,0262440 & $3,240 \mathrm{E}-02$ & \\
$\mathbf{1 4}$ & 47 & 0,21 & $-0,01$ & 0,0472855 & $4,410 \mathrm{E}-02$ & \\
$\mathbf{1 5}$ & 48 & 0,30 & 0,03 & 0,0707560 & $9,000 \mathrm{E}-02$ & \\
\hline \multicolumn{7}{c}{} \\
\hline
\end{tabular}

Dari tabel di atas maka dapat di simpulkan bahwa model matematik yang telah dibuat dapat digunakan untuk penelitian dengan nilai BSS dengan besar 0,585 dan termasuk kedalam hasil reasonable. 
3.3 Hasil Uji Coba Model Matematik (Nays2DH) Sebelum Pemasangan Krib

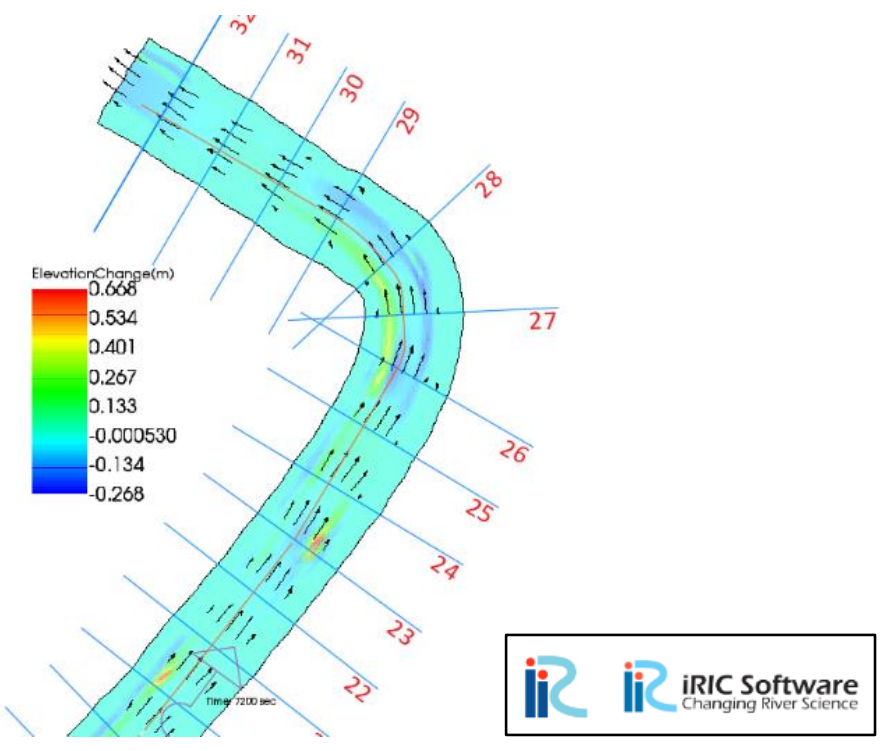

Gambar 2: Hasil uji coba Nays2DH tanpa krib dengan debit dominan

Setelah dilakukan uji coba menggunakan Nays2DH maka dapat diketahui bahwa terjadi perubahan elevasi pada dasar sungai, Perubahan yang mencolok terdapat pada bagian hilir sungai. Pada uji coba dengan debit $26,83 \mathrm{~m}^{3} / \mathrm{s}$ (dominan) terjadi gerusan pada sepanjang tikungan luar sungai, besar kedalalam gerusan adalah $0,13 \mathrm{~m}-0,26 \mathrm{~m}$. Selain itu pada sisi tikungan dalam sungai terbentuk adanya endapan, besar ketinggian endapan yang terbentuk adalah $0,13 \mathrm{~m}-0,40 \mathrm{~m}$.

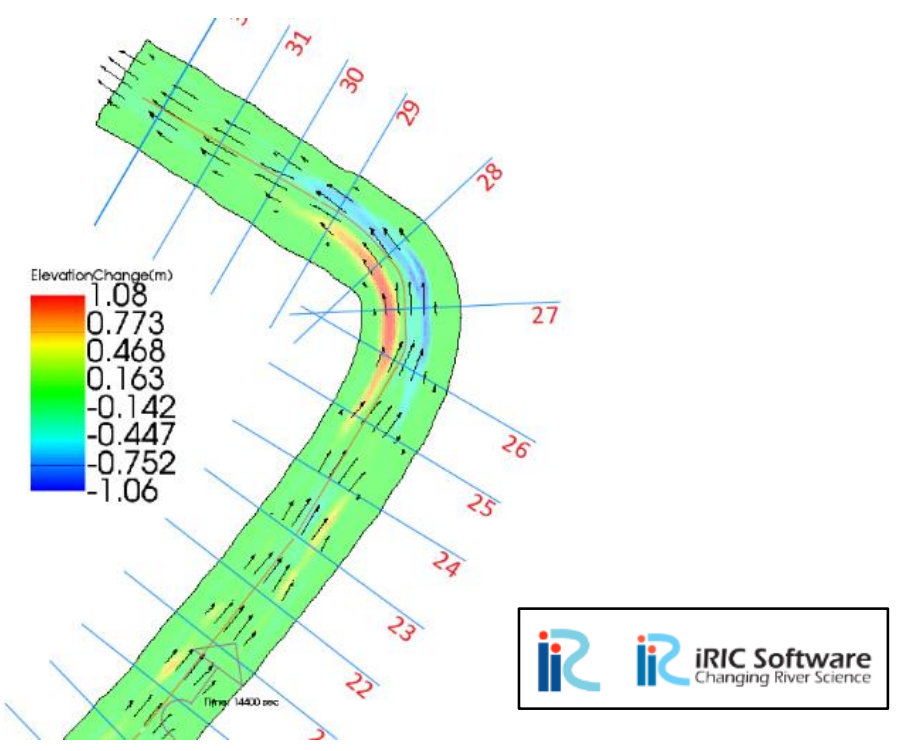

\section{Gambar 3: Hasil uji coba Nays2DH tanpa krib dengan debit dominan}

Setelah dilakukan uji coba menggunakan Nays2DH maka dapat diketahui bahwa terjadi perubahan elevasi pada dasar sungai, Perubahan yang mencolok terdapat pada bagian hilir sungai. Pada kondisi debit $53,67 \mathrm{~m}^{3} / \mathrm{s}$ (banjir) dasar sungai memiliki pola gerusan yang serupa dengan debit dominan namun pada debit banjir gerusan menjadi semakin besar, besar kedalaman gerusan yaitu 0,44 $\mathrm{m}-1,06 \mathrm{~m}$. Selain itu juga terbentuk endapan setinggi $0,16 \mathrm{~m}-1,08 \mathrm{~m}$. 


\subsection{Validasi Model Matematik Sebelum Terpasang Krib}

Berikut adalah hasil perbandingan hasil antara hasil uji coba model fisik dan hasil uji coba model matematik, melihat kedua hasil tersebut terdapat adanya kemiripan antara kedua model tersebut yaitu adanya gerusan pada tikungan luar.

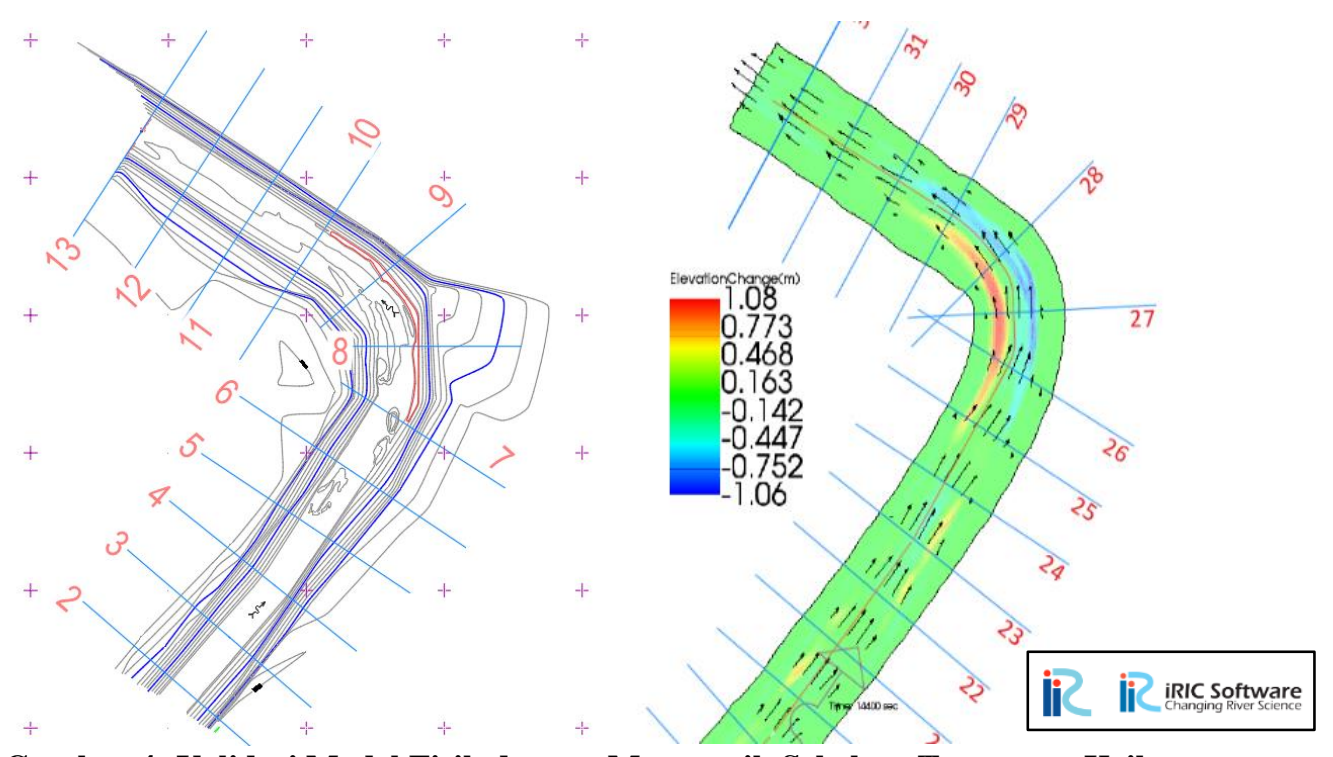

Gambar 4: Validasi Model Fisik dengan Matematik Sebelum Terpasang Krib

3.5 Perhitungan tegangan geser pada belokan

Perhitungan tegangan geser $(\boldsymbol{\tau})$ dilakukan menggunakan diagram karaki, berikut adalah rekapitulasi perhitungan tegangan geser.

Tabel 3: Rekapitulasi perhitungan tegangan geser

\begin{tabular}{ccccccccccc}
\hline Debit & $\mathrm{C}$ & $\Delta$ & $\Delta .10^{2}$ & $\Delta$ Vmax. $10^{2}$ & $2 \mathrm{X} / \mathrm{B}$ & $\mathrm{X}$ & $\mathrm{Vo}$ & $\mathrm{Vb} / \mathrm{Vo}$ & $\mathrm{Vb}$ & $\boldsymbol{\tau}$ \\
\hline Dominan & 33,51 & 0,13 & 13 & 7 & 0,5 & 11,5 & 1,7 & 1,1 & 1,87 & 3,4 \\
Banjir & 34,80 & 0,7 & 20 & 13 & 0,66 & 11,55 & 1,9 & 1,2 & 2,28 & 5,19 \\
\hline
\end{tabular}

3.6 Pemasangan Krib

\subsubsection{Penentuan Lokasi Pemasangan Krib}

Setelah melihat hasil dari running maka krib akan di tempatkan pada sepanjang tikungan luar yang terjadi gerusan, lokasi di tentukan sepanjang $100 \mathrm{~m}$ sepanjang tikungan luar.

\subsubsection{Penentuan Panjang dan Jarak Antara}

$$
\begin{array}{lc}
l=y \% \times B & \text { Pers.7 } \\
D=2,3 \times l & \text { Pers. } 8
\end{array}
$$

Dimana:

$$
\begin{array}{ll}
l & =\text { Panjang Krib } \\
\mathrm{B} & =\text { Lebar Sungai } \\
\mathrm{y} \% & =\text { Persentase lebar rencana sungai yang digunakan }
\end{array}
$$


Dengan melihat hasil ujicoba pada kondisi tanpa krib maka untuk menentukan panjang krib akan digunakan $15 \%$ lebar main channel. Melalui persamaan tersebut didapatkan panjang krib sebesar $2 \mathrm{~m}$ dan jarak antara sebesar $5 \mathrm{~m}$

\subsubsection{Penentuan Elevasi Mercu Krib}

Posisi mercu krib akan terdapat di atas permukaan air dikarenakan penampangnya lebih tinggi dari penampang basah. Tinggi mercu krib (hg) adalah 0,3 dari dari kedalaman banjir yang di rencanakan. Berikut adalah persaman yang digunakan:

$$
h g=(0,3 \times h)+h
$$

Pers.9

Dimana:

$h g$

$$
\begin{aligned}
& =\text { Tinggi mercu krib } \\
& =\text { Tinggi permukaan air }
\end{aligned}
$$

Diketahui bahwa tinggi krib adalah 3,4 m dari elevasi paling dasar +18.50 maka dari itu elevasi mercu akan terdapat pada elevasi +21.9 .

3.6.4 Diameter dan Jarak Antar Tiang Pancang

Bahan tiang pancang adalah tiang beton dengan diameter $0,3 \mathrm{~m}$ dengan jarak antar tiang pancangnya ialah $0,6 \mathrm{~m}$. berikut adalah salah satu skema pemasangan krib:

\subsubsection{Penentuan Formasi Krib}

Terdapat 3 macam formasi krib yang akan diterapkan pada studi ini yaitu tegak lurus, condong ke hulu, dan condong ke hilir.

\subsection{Perhitungan Gerusan Lokal}

Perhitungan gerusan lokal dilakukan pada tiap formasi tegak lurus (TL), condong hilir (CHi), dan condong hulur $(\mathrm{CHu})$ dua debit yaitu debit dominan dan banjir, berikut adalah rekapitulasi perhitungan gerusan lokal pada ketiga metode:

Tabel 4: Tabel rekapitulasi perhitungan gerusan lokal

\begin{tabular}{|c|c|c|c|c|c|c|}
\hline \multirow{3}{*}{ Formasi } & \multicolumn{2}{|c|}{$\begin{array}{c}\text { Metode Farraday dan } \\
\text { Charlton }\end{array}$} & \multicolumn{2}{c|}{ New Zealand Railways } & \multicolumn{2}{c|}{ Colorado State University } \\
\cline { 2 - 7 } & Dominan & Banjir & Dominan & Banjir & Dominan & Banjir \\
\hline $\mathrm{TL}$ & $2,41-3,21$ & $2,73-3,97$ & $0,27-0,34$ & $0,42-0,56$ & $0,42-0,72$ & $0,66-0,78$ \\
\hline $\mathrm{CHi}$ & $2,70-4,61$ & $3,87-5,74$ & $0,30-0,43$ & $0,42-0,60$ & $0,63-0,75$ & $0,75-0,86$ \\
\hline $\mathrm{CHu}$ & $2,50-4,17$ & $3,09-4,53$ & $0,37-0,46$ & $0,41-0,66$ & $0,52-0,65$ & $0,73-0,83$ \\
\hline
\end{tabular}


3.8 Hasil Uji Coba Model Matematik (Nays2DH) SetelahPemasangan Krib 3.8.1 Hasil Uji Coba Nays2DH Pada Formasi Tegak Lurus

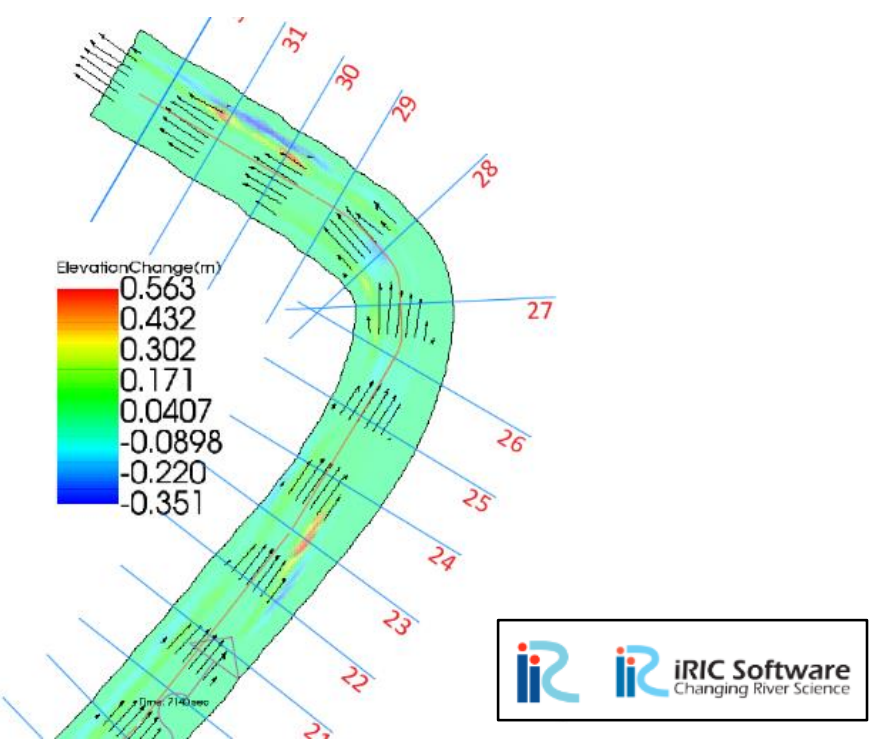

Gambar 5: Pola gerusan krib tegak lurus dengan debit dominan

Dampak yang di berikan oleh pemasangan krib tegak lurus pada debit dominan adalah terbentuknya endapan pada tikungan dalam dengan nilai kenaikan dasar saluran sebesar 0,04 $\mathrm{m}$ hingga $0,17 \mathrm{~m}$ dan terjadi gerusan pada bagian tikungan luar dengan perubahan sebesar $0,08 \mathrm{~m}$.

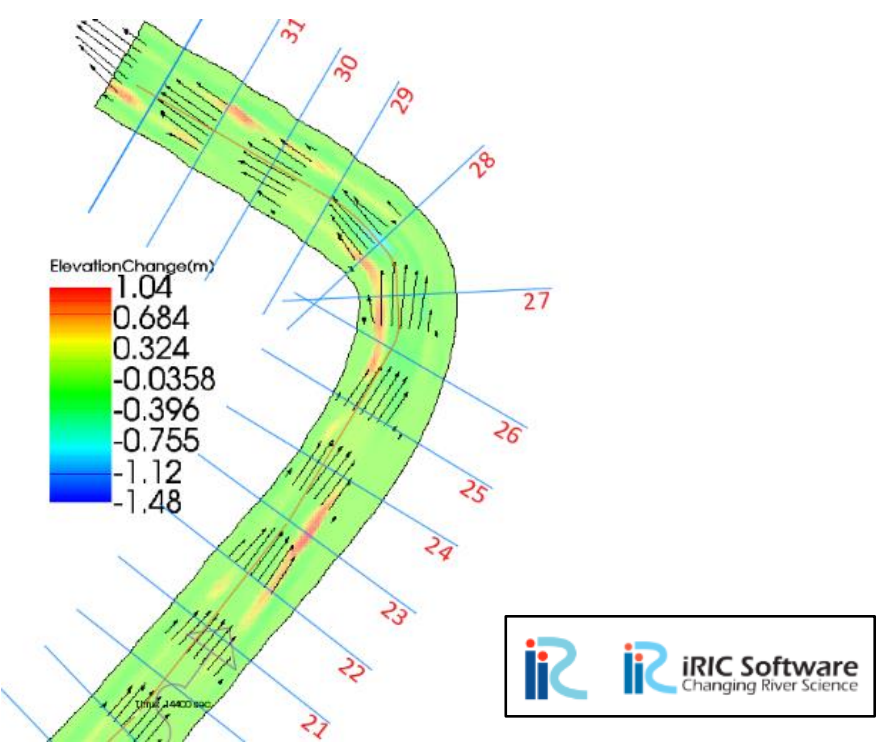

\section{Gambar 6: Pola gerusan krib tegak lurus dengan debit banjir}

Dampak yang di berikan oleh pemasangan krib tegak lurus pada debit banjir adalah terbentuknya endapan pada tikungan dalam dengan nilai kenaikan dasar saluran sebesar 0,32 $\mathrm{m}$ hingga 1,04 $\mathrm{m}$ dan terjadi gerusan pada bagian tikungan luar dengan perubahan sebesar $0,39 \mathrm{~m}$. 


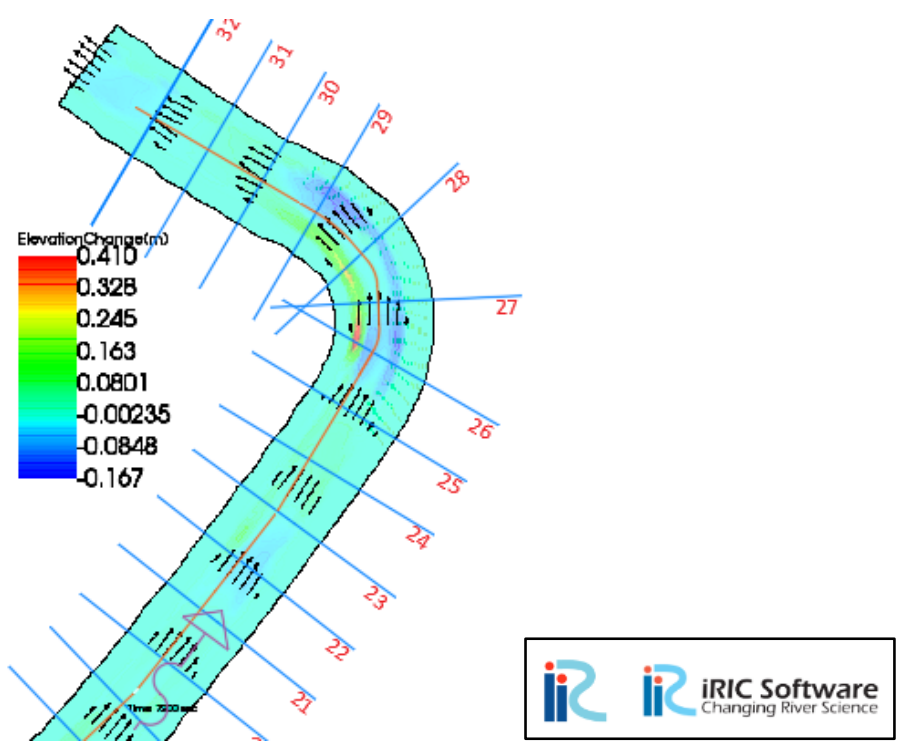

Gambar 7: Pola gerusan krib condong hilir dengan debit dominan

Dampak yang di berikan terhadap pemasangan krib condong hilir pada debit dominan adalah terbentuknya endapan pada tikungan dalam dengan nilai kenaikan dasar saluran sebesar $0,08 \mathrm{~m}$ hingga $0,41 \mathrm{~m}$ dan terjadi gerusan pada bagian tikungan luar dengan perubahan sebesar $0,08 \mathrm{~m}$ hingga $0,16 \mathrm{~m}$.

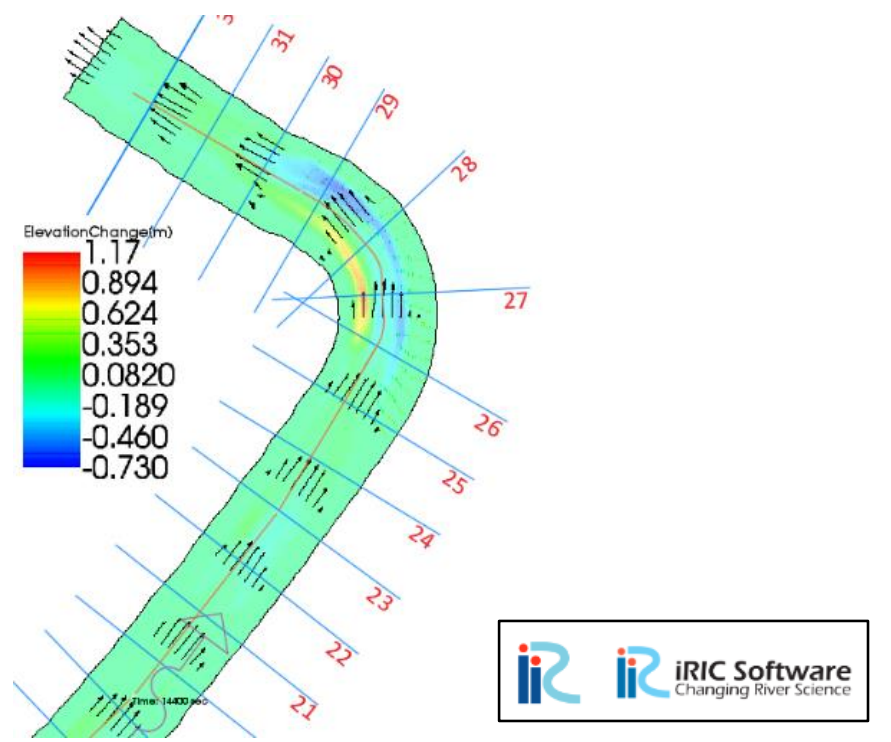

Gambar 8: Pola gerusan krib condong hilir dengan debit banjir

Dampak yang di berikan terhadap pemasangan krib condong hilir pada debit banjir adalah terbentuknya endapan pada tikungan dalam dengan nilai kenaikan dasar saluran sebesar $0,08 \mathrm{~m}$ hingga $1,17 \mathrm{~m}$ dan terjadi gerusan pada bagian tikungan luar dengan perubahan sebesar $0,18 \mathrm{~m}$ hingga $0,73 \mathrm{~m}$. 


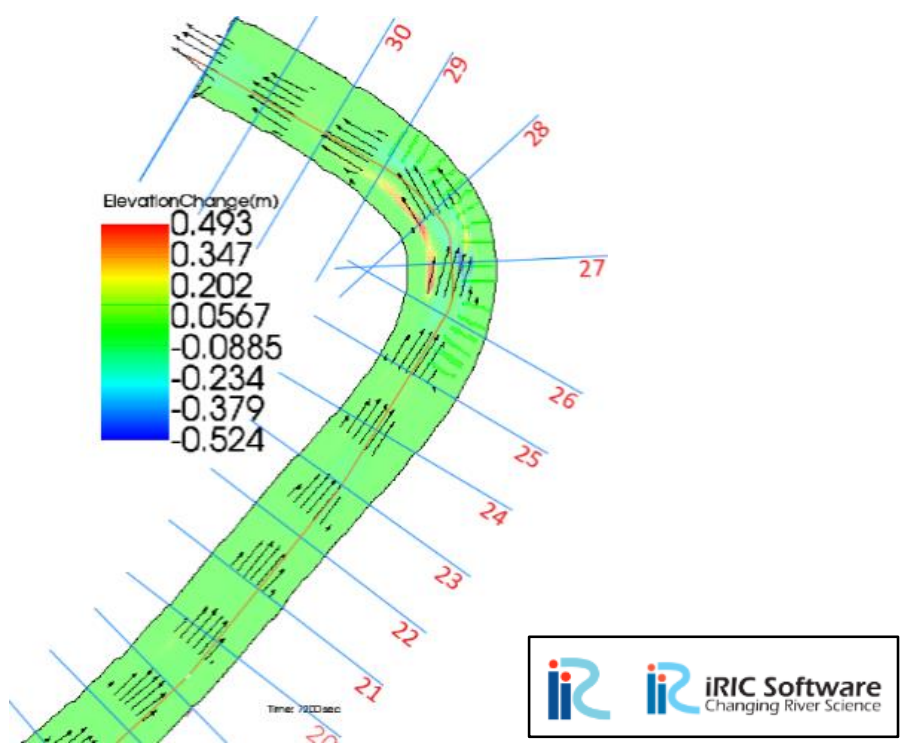

Gambar 9: Pola gerusan krib condong hulu dengan debit dominan

Dampak yang di berikan terhadap pemasangan krib condong hulu pada debit dominan adalah terbentuknya endapan pada tikungan dalam dengan nilai kenaikan dasar saluran sebesar $0,05 \mathrm{~m}$ hingga $0,49 \mathrm{~m}$ dan terjadi gerusan pada bagian tikungan luar dengan perubahan sebesar $0,08 \mathrm{~m}$ hingga $0,23 \mathrm{~m}$.

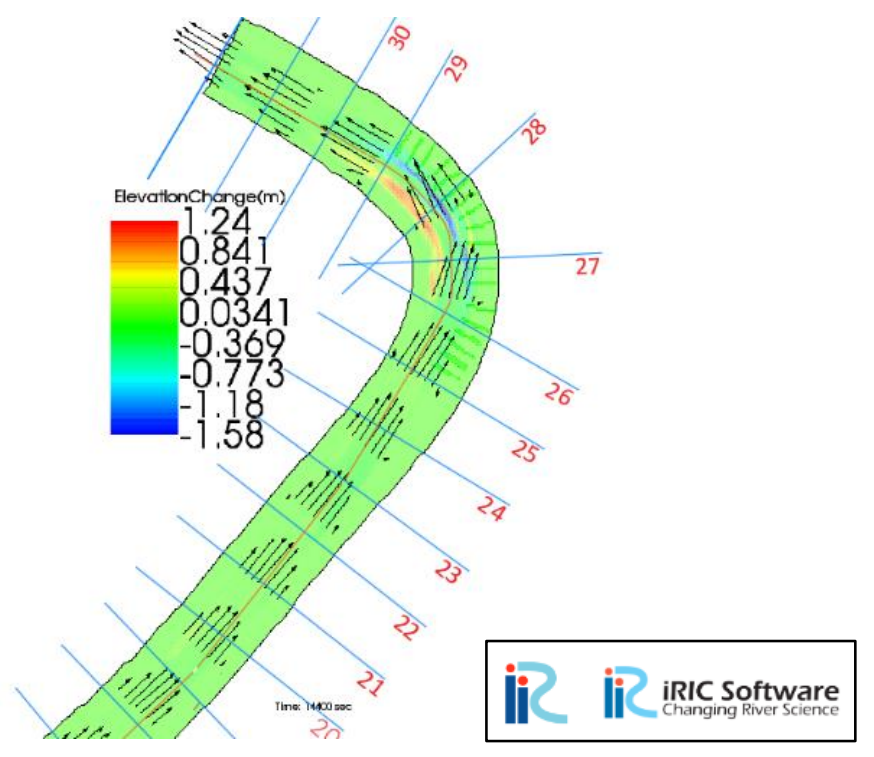

Gambar 10: Pola gerusan krib condong hulu dengan debit banjir

Dampak yang di berikan terhadap pemasangan krib condong hulu pada debit banjir adalah terbentuknya endapan pada tikungan dalam dengan nilai kenaikan dasar saluran sebesar 0,03 $\mathrm{m}$ hingga $1,24 \mathrm{~m}$ dan terjadi gerusan pada bagian tikungan luar dengan perubahan sebesar $0,36 \mathrm{~m}$ hingga $0,77 \mathrm{~m}$. 
3.9 Validasi Model Matematik Setelah Terpasang Krib

Melihat perbandingan dari kedua hasil tersebut dapat dilihat terdapat adanya kemiripan antara kedua model tersebut yaitu adanya kesamaan yaitu terjadi pengurangan gerusan pada tikungan luar.
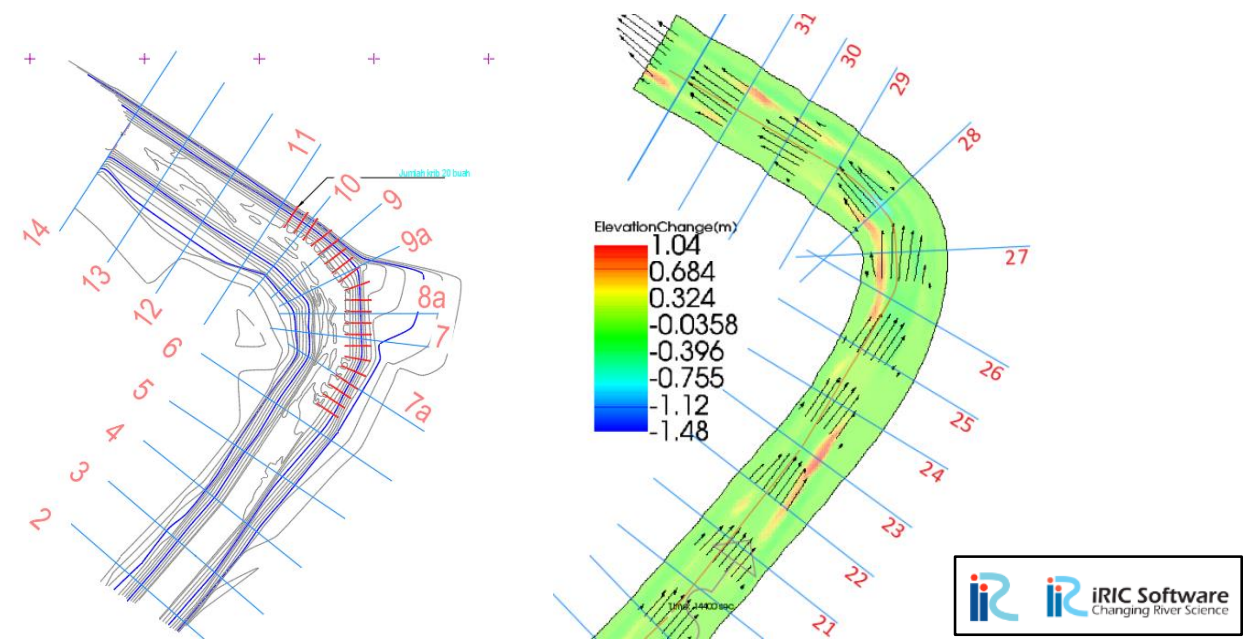

Gambar 11: Validasi Model Fisik dan Matematik Setelah Terpasang Krib Formasi Tegak Lurus
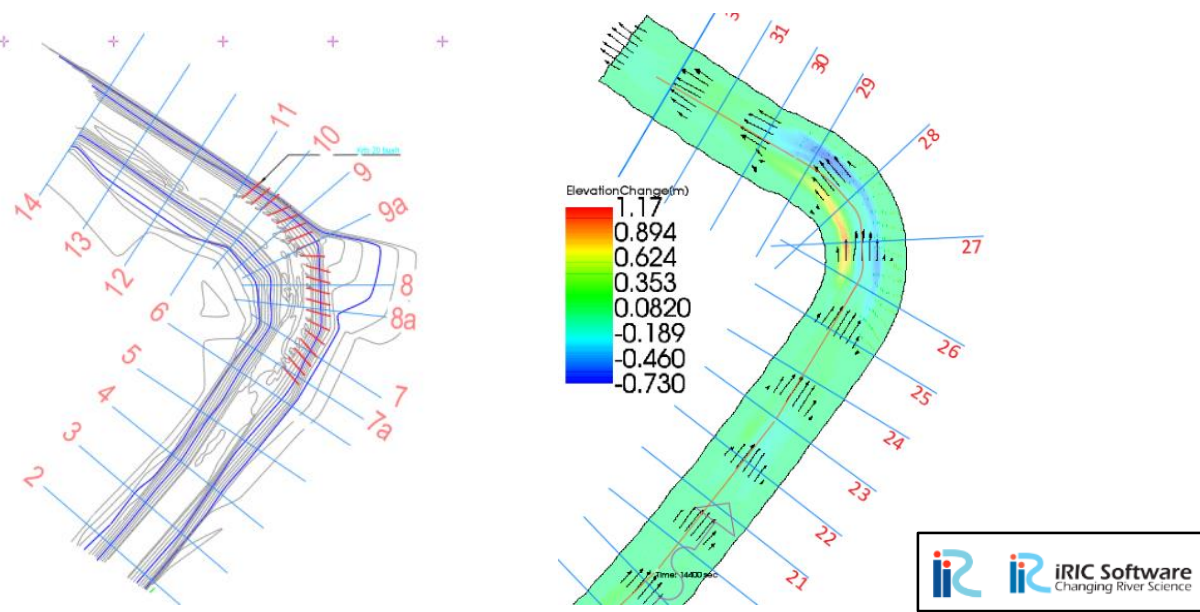

Gambar 12: Validasi Model Fisik dan Matematik Setelah Terpasang Krib Formasi Condong Hilir
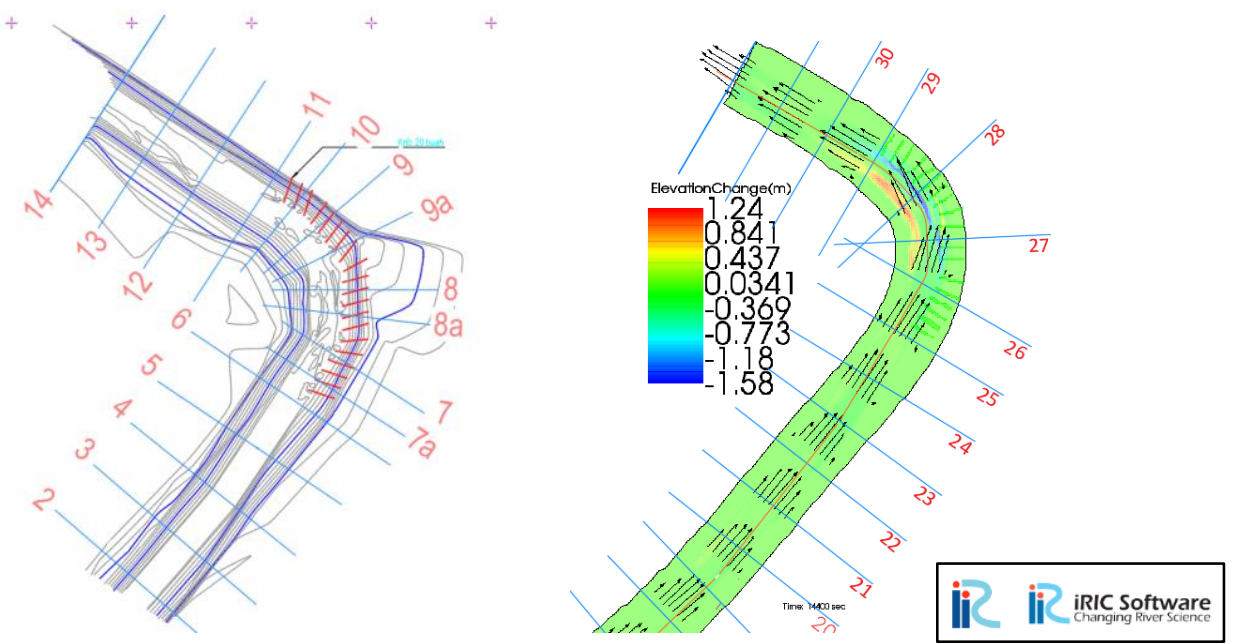

Gambar 13: Validasi Model Fisik dan Matematik Setelah Terpasang Krib Formasi Condong Hulu 


\section{Kesimpulan}

Berdasarkan hasil simulasi model fisik matematik menggunakan Nays2DH maka dapat diketahui bahwa pada belokan Sungai Ciasem pada kondisi debit dominan terjadi gerusan sepanjang tikungan luar dengan kedalaman $0,13 \mathrm{~m}$ hingga $0,26 \mathrm{~m}$ sedangkan pada kondisi debit banjir terjadi fenomena yang serupa dengan besar gerusan sebesar $0,44 \mathrm{~m}$ hingga $1,06 \mathrm{~m}$. Setelah dilakukanya pemasangan tiga formasi krib yaitu tegak lurus, condong hilir, dan condong hulu, dapat diketahui bahwa ketiga formasi tersdebut mampu mengurangi gerusan yang terjadi dengan mengarahkan gerusan menjauhi dari sisi tikungan luar,pada formasi tegak lurus terjadi gerusan sebesar $0,08 \mathrm{~m}$ pada debit dominan dan 0,39 $\mathrm{m}$ pada debit banjir, pada kondisi condong hilir terjadi gerusan sebesar $0,08 \mathrm{~m}$ hingga $0,16 \mathrm{~m}$ pada debit dominan dan $0,18 \mathrm{~m}$ hingga $0,73 \mathrm{~m}$ pada debit banjir, dan pada formasi condong hulu terjadi gerusan sebesar $0,08 \mathrm{~m}$ hingga $0,23 \mathrm{~m}$ pada debit dominan dan $0,36 \mathrm{~m}$ dan $0,77 \mathrm{~m}$ pada debit banjir. Melihat hasil dari dari ketiga formasi tersebut yang paling baik dalam mereduksi gerusan tersebut adalah formasi tegak lurus.

\section{Daftar Pustaka}

[1] Iskandar., Pitojo, T.J., dan Dian, S. "Analisa Pengaruh Penempatan Krib Terhadap Distribusi Sedimen di Pertemuan Sungai Garang dan Kreo". Jurnal Teknik Pengairan. Vol.6, No.2, pp.206-215, Desember. 2015.

[2] Suharjoko." Methode Aplikasi Bangunan Krib Sebagai Pelindung terhadap Bahaya Erosi Tebing Sungai”. Jurnal Aplikasi Teknik Sipil. Vol.5, No.1, pp.9-14, Agustus. 2008.

[3] M. H. Ayu. “Analisis Hidrolika Bangunan Krib Permeable pada Saluran Tanah”. Jurnal Teknik Sipil dan Lingkungan. Vol.2, No.3, pp.382-388, September. 2014.

[4] E. Setyono. "Krib Impermeable Sebagai Pelindung pada Belokan Sungai". Jurnal Teknik Sipil. Vol.5, No.1, pp.1-9, Februari. 2007.

[5] Farouk M., Silman P., A.A. Rahim. "Pengaruh Jarak Antar Krib terhadap karakteristik aliran pada model saluran”. Jurnal Penelitian Jurusan Teknik Sipil Univesitas Hasanudin. 2017.

[6] P. Jeni."Studi Pengaruh Krib Hulu Tipe Impermeable pada Gerusan di Belokan Sungai”. Jurnal ilmiah Mustek Anim HA. Vol. 4, No.2, pp.1-6, Agustus. 2015.

[7] D. Hasdaryatmin, S. Mary, P.H Mukhsan. "Pengaruh Krib Hulu Tipe Permeable pada Gerusan di Belokan Sungai”. Jurnal Sipil. pp.153-157, April. 2012.

[8] Sunaryo, D. Darwizal, L.S. Febby."Pengaruh Pemasangan Krib pada Saluran di Tikungan 120”. Jurnal Rekayasa Sipil. pp.45-53, Vol.6, No.1, Februari. 2010.

[9] J. Widhiasmoro, P. G. Putra, S. Salamun, and A. Kadir, "Pemanfaatan Krib Untuk Penggelontoran Sedimen pada Muara Sungai (Studi Kasus Muara Sungai Juwana)," Jurnal Karya Teknik Sipil. pp.97-104, Vol. 2, No.4, Oktober. 2013.

[10] L. Hilda, M. Asep, M. Dedi. “ Kesesuaian Lahan Berdasarkan Indeks Konservasi Secara Spasial di DAS Ciasem Hulu, Subang". LIMNOTEK: Perairan Darat Tropis di Indonesia. pp.119-129, Vol.16, No.2, Agustus. 2019. 